\title{
El advenimiento de una nueva realidad en Mujeres, sombras y coloquios de uno, de Eduardo Vargas Ugalde
}

\section{Seidy Araya}

Universidad Nacional de Costa Rica

Parecería, en efecto, que para el novelista de linaje fantástico, el que describe mundos irreconocibles y notoriamente inexistentes, no se plantea siquiera el cotejo entre la realidad y' la ficción. En i'erdad, si se plantea, annque de otra manera. La irrealidad de la literatura fantástica se viuelie, para el lector; símbolo o alegoría, es decir; representación de realidades, de experiencias que si puede identificar en la vida. Mario Vargas Llosa. La verdad de las mentiras.

El volumen Mujeres, sombras y coloquios de uno está formado por veintinueve cuentos breves. Son relatos condensados e intensos. A partir de la narración de anécdotas muy someras, los cuentos despliegan inquietudes existenciales de aliento poético y filosófico.

El autor, Eduardo Vargas Ugalde, nació en Naranjo de Alajuela en 1944. Es microbiólogo graduado en la Universidad de Costa Rica y ha trabajado como funcionario del Hospital de Niños mayormente en jornadas nocturnas. Dirige ahora el Departamento respectivo de ese centro de salud. Hombre de lecturas clásicas y medievales, se interesa también por las primicias contemporáneas. Dentro de su formación como escritor, destaca su asistencia al taller del poeta Laureano Albán y a otros círculos creativos. Uno de sus primeros cuentos, «Eloy», obtuvo el tercer lugar en el concurso de la revista francesa La porte de poétes (París, 1985). Obtuvo el tercer lugar con «La caja secreta», en 
el concurso literario para empleados de la Caja Costarricense de Seguro Social (1966), certamen asesorado por la Escuela de Literatura y Ciencias del Lenguaje de la Universidad Nacional. En 1995 publicó Historias para leer en una noche. El volumen que hoy nos ocupa recibió el premio Editorial Costa Rica 1996 y el Premio Nacional de Literatura en la rama de cuento Aquileo J. Echeverría dos años después. Tiene inédita una novela y continúa su labor literaria.

El tema abarcador del volumen es la trascendencia a los límites de una vida humana. Los personajes realizan diferentes tipos de rupturas respecto a las limitaciones de una existencia material —asfixiada por rígidas coordenadas espacio-temporales y oprimida por ambientes solitarios, tediosos y enajenantes- en busca de mejores universos.

Las rupturas toman a menudo la forma de desplazamientos geográficos, tales como viajes del campo a la ciudad, travesías de la urbe moderna a la antigua, navegaciones, paseos en bicicleta, caminatas que culminan con el conocimiento de aspectos inusuales de la realidad. En otras ocasiones, los cuentos recurren a dislocaciones temporales en las que irrumpen fragmentos del pasado y seres fantasmales que permiten la recuperación de acontecimientos silenciados o de valores en peligro de extinción. A veces, se rompen los límites entre la vida consciente y las profundidades del inconsciente para que los personajes liberen la energía de su libido e impulsen el advenimiento de un cosmos renovado. También se produce un traslado de los personajes desde el mundo terrenal al espacio dorado de la muerte, desatada ya el alma de sus cadenas corpóreas.

En todos los casos, la presencia de elementos simbólicos condiciona la transformación del tiempo, del espacio y de la interioridad de los personajes. Tal y como lo sugiere el título, algunos de los símbolos son las imágenes femeninas y las sombras nocturnas, donde se sitúan los coloquios de personajes que sufren una mutación fantástica de su circunstancia. Un papel fundamental en el acontecimiento maravilloso juegan los objetos como los espejos, los vidrios de ventanas, puertas, vasos, collares o su sustancia gemela, el agua, que posibilitan 
un nuevo reflejo de la realidad habitual y abren el misterio de universos paralelos. A menudo, el nuevo cosmos alcanzado se representa en la casa, recuerdo del útero materno, pozo del inconsciente, residencia de los valores auténticos como la solidaridad, la fortaleza, la vitalidad, la fecundidad y la imaginación erótica.

Los personajes femeninos se comportan como intermediarios entre la realidad cotidiana o «normal» y el espacio trascendente. Son las guías y las depositarias de las llaves o de los poderes que permiten el acceso al paraíso buscado. Por esa razón, los cuentos están precedidos por un epígrafe de la Divina Comedia, en el que se observa a Beatriz en el lado oscuro del globo, mirando hacia el sector contiguo alumbrado por la luz solar positiva.

Hecho había acá noche, allá mañana desde ésa, y uno en sombra se acobija, $y$ otro hemisferio en blanco se engalana, cuando a Beatriz vi prolija,

y al lado izquierdo vuelta, al sol derecho, águila nunca así le vio tan fija ${ }^{l}$.

En los cuentos, el traslado desde un sitio engañoso e inauténtico, a otro lugar extraño, pero verdadero sucede en la noche, propiciado por las brumas de un rojizo atardecer o por las nacientes luces de la madrugada y en la mayoría de los relatos, bajo la luz femenina y misteriosa de la luna entre nubes. Esta clase de luminosidad promueve la confusión y la ambigüedad de las sombras.

La opción predominante por un narrador protagonista de sus propias aventuras en muchos cuentos, los presenta como vivencias subjetivas de cuyo verismo puede dudarse. Tanto el protagonista como el lector se asombran y vacilan ante los acontecimientos fantásticos y los desenlaces inesperados.

1. Dante. El Paraiso. en Eduardo V'argas L Lgalde. Mu jeress, sombras y' coloquios de uno (San José: Editorial Costa Ricia. 1998) \&. En adelante se indicará solamente el número de pảgina. 
Además, los datos espaciales tienden a ser deliberadamente imprecisos, lo que contribuye a la ambigüedad textual. Apuntan, sin embargo, a un entorno hispanoamericano generalmente urbano, aunque también se dibujan espacios campestres. Los elementos arquitectónicos y paisajísticos se hallan estilizados, de manera que devienen símbolos de otros tiempos o del mundo interior. La mayor parte de los anclajes históricos están difuminados, pero igualmente cargados de esencias históricas provenientes de la época prehispánica y colonial.

Así, es posible identificar en algunos cuentos referentes históricos costarricenses o suramericanos. La ciudad de Quito es especialmente aludida en algunos relatos como espacio propicio para los acontecimientos maravillosos, gracias a su riqueza histórica indígena y a la conservación de la arquitectura virreinal. Tan fantasmagórico resulta el entorno quiteño, como el Oriente de las Mil y una noches, obra que preside la inspiración de ciertas narraciones. La sensibilidad del narrador hacia los misterios encerrados en Quito es compartida por visitantes, que opinan así:

La capital del Ecuador se halla en un alto valle intrandino, a tres kilómetros sobre el nivel del mar, y en verdad que es una ciudad cuasi celeste, antesala o zaguán del paraíso ${ }^{2}$.

Mediante el recurso a los elementos fantásticos y a la transmutación de la ordinaria realidad, el volumen Mujeres, sombras y coloquios de uno logra la auscultación de problemas metafísicos, la revisión crítica de los legados históricos de la América Hispánica y la indicación de modalidades diversas de opresión y censura sociales sobre el individuo pensante y vital. Por lo tanto, los cuentos, aunque no lo parecen en una primera lectura superficial, son profundamente subversivos porque defienden la libertad de pensamiento y expresión de las personas y de las comunidades.

2. Ernesto La Orden Miracle, "Quito, puerta del cielo. Elogio de la luz y del empiazamiento de Quito». en Elogio de Quito. Cuadernos de arte, Serie B.I. Prólogo del Marques de Lozoya (Madrid: Ediciones Cultura Hıspánica. 1950) 15. 
Sobre la base de estas hipótesis preliminares, procedamos a comentar uno de los relatos titulado «El pozo». La fábula escueta refiere una experiencia fantástica que sufrió el narrador protagonista y anónimo. Mientras cenaba en un restaurante de origen y edificio colonial, una dama desconocida llegó a comer allí. Le mostró el pozo ubicado en el centro del jardín donde había antes una laguna y un pueblo grande, junto al Camino de Vencidos. Le informó queen la fachada de la hospedería se realizó la primera pintura herética del país en el siglo XVI.

El narrador no encuentra ninguna información sobre la hospedería en el Archivo Urbano al día siguiente. Esa noche, la dama le revela que la pintura fue ahogada en la antigua laguna por la Inquisición. De manera extraordinaria, el narrador logra percibir una visión de la laguna, del pueblo y del antiguo camino, como prueba de la veracidad de la información y sospechaque la dama es el fantasma de la pintora asesinada.

La época histórica que recupera el cuento es el siglo XVI y nos of rece la fecha específica de 1587. Además nos indica un topónimo, el Camino de Vencidos. Esta vía no tiene referente histórico. El presente del relato corresponde a una ciudad que conserva mucha de su arquitectura del siglo XVI. La vetusta arquitectura de Quito, así como los altos logros en esa disciplina, en pintura y escultura durante la época colonial, sirven de inspiración. Además de los indicios arquitectónicos y plásticos, el cuento of rece pistas léxicas para sugerir la ubicación, al mencionar las sierras cercanas a la hospedería, lo que recuerda el asentamiento de Quito en las mesetas de los Andes. Sin embargo, el cuento podría situarse en cualquier país hispanoamericano sin perder un ápice de su significado.

La espina dorsal del Ecuador, esa región que los ecuatorianos llaman simplemente «La Sierra», pudiera definirse como la «Avenida de los Volcanes Nevados», una gran calle de praderas y de ciudades, flanqueadas a entrambos costados por montes preñados de fuego pero vestidos de nieve ${ }^{3}$.

3.

Ibíd.. 55. 
La afirmación de que Quito es la urbe generadora del espacio textual se fundamenta, asimismo, en la importancia de los edificios barrocos en la narración. Aunque tanto en Guatemala, como en Venezuela y Colombia, florecieron las artes decorativas, la pintura y la arquitectura en la época colonial, sin embargo, Ecuador, México y Perú son las sedes de las obras más logradas. Particularmente, Quito representa el máximo desarrollo artístico de raíces diversas, tanto que el centro histórico ha sido declarado patrimonio de la humanidad. Esta producción retoma los acentos precoloniales — es decir, el legado del pueblo quitu antes del siglo XI y luego los aportes del imperio inca desde 1484-, bajo los modelos flamencos portados por los franciscanos como Plino Goseseal o Jodoco Ricke de Marselaer, llegados a Quito en 1534 con los primeros conquistadores tras la huella del dominador Sebastián de Balalcázar. Ricke fue fundador del convento de San Francisco y de la escuela de artes y oficios de San Andrés. En los siglos posteriores, es muy reconocida la Escuela Quiteña de escultores y pintores. Sus más aplaudidos miembros fueron los pintores Miguel de Santiago y Nicolás de Goríbar, y los escultores como el Padre Carlos en el siglo XVII y el indígena Manuel Chili, llamado Caspicara en el siglo XVIII.

La situación inicial muestra al narrador protagonista en una actividad normal y cotidiana: cena en su restaurante habitual, una hospedería de origen colonial. Sin embargo, un elemento de la fachada, que percibimos gracias a la mirada del narrador, evoca una época histórica anterior. Son unas oraciones, calificadas de epígrafe por el narrador, en calidad de letrero claveteado en el dintel: «La hospedería donde se alojaron y bastimentaron pacificadores y doctrineros que iban de paso a las sierras» (49).

Estas palabras confieren visos de realismo al hecho de que la hospedería existía desde la época de la Conquista y Colonización de América por España. Persuaden al lector de la historicidad de los acontecimientos que se narrarán. Al mismo tiempo, hermanan la casona con un texto literario dado que tiene en su pórtico un epígrafe. 
De manera que es posible esperar que una de las dimensiones semánticas del cuento se relacione con un concepto de la literatura y de las funciones del discurso literario.

Es usual también en el narrador entrar al restaurante «bordeando el jardín» (49) y sin mirar el pozo ubicado en el centro de la construcción, junto a una cruz «de piedra florecida que se plantaba en las plazas» (49). Tantoel epígrafe del dintel como el detalle arquitectónicodel pozo junto a la cruz deslizan el presente hacia el pasado colonial.

Se intensifica el movimiento de ruptura entre los hábitos del narrador y las circunstancias especiales de ese día. Una mujer de unos cuarenta y tantos años ha ocupado la silla preferida del narrador protagonista, próxima a un «portalón barroco, de caprichosas tallas y vidrios curvos que falseaban los rojos del sol vesperal» (50).

Se ha producido un cambio de sitios. El narrador abandonará su perspectiva usual en la hospedería, que le había oscurecido la percepción profunda del lugar. Empezará a mirar por medio de los ojos extraños de la dama. La transformación se sugiere en los pedazos de vidrio de un vaso roto, que se le ha caído a la dama y ha recogido el protagonista. La señora solitaria parece haber esperado al caballero para ampliar su bagaje de conocimientos superficiales o lógico-racionales e introducirlo a una realidad más compleja. Por esa razón, la dama usa «unas gafas de lentes en gota» (50). La última palabra nos remite al pozo, cuya agua funciona como un espejo reflectante de los aspectos ignorados de la historia del país.

Se da el coloquio entre la mujer y el personaje principal, donde ella cuestiona los elementos antes invisibles e indiferentes para él, con un «aire de sacerdotisa oriental» (50). Estos adjetivos confirman la tarea mediadora de la fémina entre el mundo ordinario del narrador y el milagro que ella le permitirá observar. Usualmente, los calificativos orientales subrayan en los cuentos los fenómenos mágicos.

La dama permanece anónima y no interesa su caracterización, sino su función motivadora hacia una mayor sabiduría en el protagonista. Ella lo hace superarse, desarrollar sus potencialidades como «el 
grande, el averiguador de la existencia», como se refieren los mayas en el Pop Vuh al ser humano y a su capacidad heurística ${ }^{4}$. «QQué sabe de este lugar?» (50). Como se trata de un problema de conocimiento histórico, el narrador señala que ella «rezaga» (50) las palabras. La dama le revela que en el frontón de la vieja hospedería, una mano femenina hizo la primera pintura herética del país en el siglo XVI y que ella investiga el asunto. Así se introduce en el relato una temática contestataria respecto a las instituciones coloniales represivas como la Inquisición y la Iglesia Católica, que se repite en muchos de los cuentos. La mu jer agrega que antiguamente en el sitio del pozo existía una laguna, bordeada por el Camino de Vencidos y por un pueblo grande.

Al día siguiente, el narrador procura estudiar el caso mediante métodos históricos objetivos. Busca en el Archivo Urbano los mapas y bosquejos de los antiguos edificios. No encuentra dato alguno sobre la hospedería. Está borrada de la historia, como la laguna cerca del Camino de Vencidos. Está ante lo increíble. A la plena luz del sol, el misterio no entrega sus claves.

Cuando cae de nuevo la noche, el narrador dedica muchas horas a la contemplación del pozo; iluminado por el brillo lunar en medio de las sombras, extrañas y maravillosas luce como un «abismo de voces ahogadas» (51). Asociada con la aparición de la luna, aparece de nuevo la dama, en el escenario propicio a la revelación del misterio: «La luna pasaba con disimulo tras una embolia de nubes, recortando sombras chinescas» $(51)$.

El cuento ha ido dosificando las informaciones y los indicios de forma que se mantiene la tensión acerca del porqué de las omisiones históricas y acerca de la suerte de la pintora, rebelde a los dogmas en el siglo XVI.

Las imágenes de la mujer en el jardín, los coloquios en las sombras se hacen posibles por la nueva visión, por el cambio de intereses y de perspectivas que ha sufrido el narrador, aludidas en el

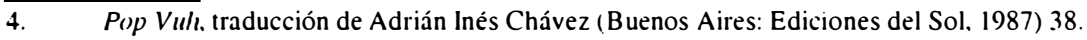


agua del pozo y en la antigua laguna, que son espejos que denuncian ciertas verdades relegadas o silenciadas por la historia, en este caso, un asesinato por ahogamiento de la pintora herética, que osó desairar a la Inquisición. Por eso aparece la cruz a la par del pozo.

Sobrecogido, el protagonista sospecha que está ante el fantasma de la artista asesinada en la época colonial y como prueba de orden sobrenatural vio «extenderse una laguna y, más allá, los trazos de un pueblo en ruinas» (52). El espacio arrasado por la Inquisición y borrado en los documentos históricos es recuperado mágicamente al conjuro del agua del pozo y la dama en el jardín «sumergida en alguna ambivalencia de la noche»; «aligerando el aire mixturado de arcanos» (52).

Estos términos aluden a la ambigüedad persistente en el sentido del cuento. El protagonista y' el lector titubean y no saben cuáles hechos deben aceptar como verdaderos, dada la mezcla de los planos del presente ordinario y el pasado fantasmal.

El final del cuento retoma las expectativas creadas en la situación inicial en torno al concepto de literatura y las funciones del discurso artístico. La presencia sobrenatural de la dama en la vieja hospedería se explica en relación con la capacidad de la ficción para asumir la voz de los artistas, de los intelectuales y del pueblo en peligro de ser ahogados, de ser asfixiados por fuerzas autoritarias que rechazan las posturas disidentes.

- Pero debo advertir a cuantas vayan de paso. El Camino de Vencidos lleva a la laguna y de allí al pueblo, donde vive tanta gente como muertos hubo en otros tiempos (52).

El Camino de Vencidos, topónimo imaginario, connota la ruta trágica que siguen los rebeldes, si no se defienden adecuadamente: la ruta del silenciamiento y de la muerte. Por contraste, un sentido abarca el destino de los pueblos originarios subyugados por los españoles. Recuérdese que los conquistadores desfilaron por el Camino de los Caballeros, en Dominicana, para dispersarse por el continente. En 
general, el cuento se refiere al dolor ante los despotismos coloniales y también alza la voz en alerta contra las coerciones actuales. A causa de esas razones, no interesa tampoco que, a pesar de la precisión en la fecha, el cuento const ruya imaginariamente un hecho represivo, el asesinato de una pintor a herética sin referente histórico específico. Lo importante, desde el punto de vista estético, es que el suceso ficcional se justifica en el mund $\boldsymbol{O}$ colonial, donde la Inquisición jugó un papel fundamental en el sojuzgamiento de la libre opinión y que la dama misteriosa se convierte en un símbolo de la libertad conculcada. El cuento lanza su advertencia para que sucesos trágicos semejantes no aparezcan de nuevo en la historia. En este sentido, el relato alcanza universalidad al ocuparse del tema de la libertad. 